\title{
Determinan Aktivitas Fisik Orang Dewasa Pekerja Kantoran di Jakarta Tahun 2018
}

\author{
Dinanti Abadini $^{*}$, Caroline Endah Wuryaningsih") \\ ${ }^{*}$ Fakultas Kesehatan Masyarakat Universitas Indonesia \\ Korespondensi: endah1@ui.ac.id
}

\begin{abstract}
Background: Benefits of adult physical activity for health maintenence and disease prevention have been extensively documented. Sedentary occupation believed as a factor which contributes to office workers insufficient physical activity. Jakarta was the province with the highest proportion of insufficient physical activity (44.2\%). Majority workers in Jakarta were as office workers. This study aims to analyze determinant factors influence to physical activity of office workers in Jakarta City.
\end{abstract}

Method: The research was conducted in quantitative method using a cross-sectional approach. A total of 174 Jakarta's office workers have participated in online questionnaire by submitting response via website. The questionnaire to measure the level of physical activity used in this study is Global Physical Activity Questionnaire (GPAQ) which is developed by WHO. This questionnaire measures a lot of time spent on physical activity at work, travel (transportation) and also free time in one week which is then converted into units of metabolic equivalents (METs). These METs scores were then categorized to be quite physically active (METs $\geq 600)$ or less physically active (METs $<600)$.

Results: The study found that 59\% of office worker who work in Jakarta had insufficient physical activity. Statistical anlysis revealed that male, friends support and low perceived barriers were the factors influenced sufficient physical activity of office workers. Health intervention and promotion which intend to reduce perceived barriers, and increase perceived benefits of doing physical activity, encourage friends to support to increase physical activity of workers are needed to be developed. In addition, special attention should be given to female office workers in order to increase their participation in physical activity. Keywords: Physical activity, office worker, perceived barriers, benefits

\section{PENDAHULUAN}

Manfaat dari aktivitas fisik
terhadap kesehatan sudah banyak
diketahui. $^{(1)(2)}$ Pada orang dewasa, aktivitas
fisik diperlukan untuk mengurangi risiko
terjadinya berbagai penyakit dan kematian
dini. Ketidakaktifan fisik diestimasi
menyebabkan $6 \%$ hingga $10 \%$ kejadian
penyakit tidak menular, seperti penyakit
jantung koroner, diabetes dan kanker
(payudara dan kolon). ${ }^{(3)(4)}$ Selain

bermanfaat untuk kesehatan fisik, aktivitas fisik juga dinilai baik untuk menjaga kesehatan mental orang dewasa. Aktivitas fisik teratur memiliki efek positif dalam mengurangi stres dan kecemasan. Pada gangguan depresi ringan hingga sedang, aktivitas fisik juga dipercaya memiliki efek yang bermanfaat dalam mencegah dan menyembuhkan. ${ }^{(5)}$

Meski sudah banyak bukti yang menyampaikan manfaat dari aktivitas fisik, 
tetapi masih cukup banyak orang dewasa yang tidak melakukan aktif fisik. WHO menyebutkan, secara global, satu dari empat orang dewasa kurang melakukan aktivitas fisik. ${ }^{(6)} \mathrm{Di}$ Indonesia, tercatat $26,1 \%$ penduduk termasuk dalam kategori dengan aktivitas fisik kurang. Jakarta merupakan provinsi dengan proporsi penduduk yang kurang aktivitas fisik tertinggi, tercatat masih ada 44,2\% penduduk yang kurang melakukan aktivitas fisik. ${ }^{(7)}$ Sebuah survei mengenai gaya hidup sehat pada para pekerja usia dewasa di Jakarta juga menunjukkan kecenderungan yang sama. Sebagian besar pekerja di Jakarta adalah pekerja kantoran. Mereka menghabiskan waktu lebih dari 8 jam di kantor dan 2 hingga 4 jam di perjalanan, baik menuju kantor ataupun pulang ke rumah, yang membuat tidak adanya waktu untuk bergerak aktif sehingga cenderung menyebabkan ketidakaktifan fisik. Bahkan 23,8\% responden yang terdiri dari mayoritas wanita mengaku tidak berolahraga sama sekali. $^{(8)}$

Terdapat berbagai faktor yang dilihat berhubungan dengan aktivitas fisik orang dewasa pekerja kantoran. Kelompok pria ditemukan lebih aktif secara fisik dibandingkan wanita. Usia dewasa yang lebih muda, lebih aktif secara fisik dibandingkan dengan mereka yang usianya lebih tua. Berstatus menikah juga ditemukan berhubungan dengan aktivitas fisik yang kurang. Semakin tinggi jenjang pendidikan, semakin rendah tingkat kegiatan aktivitas fisik seseorang. ${ }^{(1)(9)(12)}$ Adanya riwayat penyakit kronis, terdiagnosa hiperkolesterolimia dan kondisi berat badan ditemukan berkorelasi dengan aktivitas fisik. ${ }^{(9)(13)(14)}$ Orang dewasa yang memiliki persepsi positif akan manfaat dari aktivitas fisik (perceived benefits), seperti dapat mencegah penyakit, menjadi cara untuk memperoleh bentuk tubuh ideal atau menghilangkan stres, cenderung melakukan aktivitas fisik lebih banyak dibandingkan yang tidak memiliki persepsi positif. Sebaliknya orang dewasa yang memiliki persepsi negatif tentang adanya penghalang untuk aktif fisik (perceived barriers) yang tinggi cenderung tidak melakukan aktivitas fisik. ${ }^{(14)(15)}$

Di tinjau dari aspek sosial dan lingkungan, adanya dukungan dari orang lain untuk melakukan aktivitas fisik membuat individu cenderung lebih aktif secara fisik.(1)(15)(16) Lingkungan tempat kerja dimana mereka kebanyakan menghabiskan waktu dan keseharian juga dilihat sebagai faktor yang berkaitan dengan aktivitas fisik. ${ }^{(17)}$ Sarana transportasi aktif yang digunakan untuk menuju ataupun pulang dari tempat kerja juga dilihat sebagai faktor yang berperan terhadap aktivitas fisik orang dewasa. Transportasi aktif adalah metoda untuk 
berpindah dari satu tempat ke tempat lain dengan melakukan aktivitas fisik, seperti berjalan kaki, bersepeda ataupun memanfaatkan sarana transportasi umum massal. $^{(18)}$

$$
\text { Membaiknya kesejahteraan, }
$$

kemajuan teknologi dan kurang baiknya tata kota dianggap berkontribusi terhadap kurangnya aktivitas fisik pada penduduk dewasa usia produktif di Jakarta. ${ }^{(19)}$ Oleh karena itu, penelitian ini bermaksud untuk mengetahui faktor-faktor yang berhubungan dengan aktivitas fisik pekerja kantoran yang bekerja di wilayah Jakarta. Dengan demikian, diharapkan hasil penelitian ini dapat menjadi masukan dan bahan pertimbangan dalam menyusun program promosi kesehatan yang mendukung peningkatan aktivitas fisik pekerja kantoran di Jakarta.

\section{METODE}

Desain studi cross-sectional dengan pendekatan metode kuantitatif. Pengumpulan data dilakukan melalui kuesioner dengan memanfaatkan Google Form sehingga data diperoleh secara online. Partisipan dari penelitian ini adalah orang dewasa pekerja kantoran yang bekerja di wilayah Provinsi DKI Jakarta pada bulan Maret hingga April tahun 2018. Kriteria partisipan adalah 1) usia dewasa 21- 58; 2) pekerja kantoran; 3) dapat mengakses kuesioner secara online; dan 4) bersedia berpartisipasi dalam penelitian ini. Iklan mengenai penelitian disebar melalui media dan jejaring sosial beserta keterangan kriteria pertisipan. Calon partisipan dapat berpartisipasi secara sukarela dengan mengakses tautan dari kuesioner. Penjelasan dan persetujuan responden (informed consent) dikonfirmasi sebelum memasuki item-item pertanyaan dari kuesioner.

Kuesioner penelitian disusun untuk melihat hubungan faktor karakteristik individu (usia, jenis kelamin, status nikah, pendidikan, pendapatan), status kesehatan (IMT dan riwayat penyakit), psikologis (perceived benefits dan perceived barriers), dukungan sosial (dukungan keluarga dan dukungan teman) dan lingkungan (promosi aktivitas fisik di tempat kerja dan transportasi aktif) dengan tingkat aktivitas fisik pekerja kantoran yang bekerja di Jakarta.

Kuesioner untuk mengukur tingkat aktivitas fisik yang digunakan dalam penelitian ini adalah Global Physical Activity Questionnaire (GPAQ) yang merupakan kuesioner yang dikembangkan oleh WHO. Kuesioner ini telah diterjemahkan dalam Bahasa Indonesia dan digunakan sebagai bagian dari Riskesdas tahun 2013 serta berbagai penelitian aktivitas fisik di Indonesia. ${ }^{(20)(21)}$ Kuesioner ini mengukur banyak waktu yang dihabiskan untuk aktivitas fisik dalam 
bekerja, perjalan (transportasi) dan juga waktu luang dalam satu minggu yang kemudian dikonversikan dalam satuan metabolic equivalents (METs). Skor METs ini kemudian dikategorikan menjadi cukup aktif fisik (METs $\geq 600$ ) atau kurang aktif fisik (METs < 600).

Pengukuran perceived benefits dan perceived barriers dilakukan menggunakan adopsi kuesioner Excercise Benefits/Barriers. ${ }^{(22)}$ Terdiri dari 23 item pernyataan yang mengukur persepsi manfaat dan juga persepsi hambatan yang diantaranya seperti 'Aktivitas fisik meningkatkan tingkat kebugaran fisik saya', 'Aktivitas fisik mengurangi stres dan ketegangan saya', 'Aktivitas fisik memperbaiki tampilan bentuk tubuh saya', 'Saya merasa kesulitan dalam meluangkan waktu untuk melakukan aktivitas fisik rutin', 'Aktivitas fisik rutin merupakan pekerjaan berat yang sulit untuk saya lakukan'.

Kuesioner faktor dukungan sosial diadopsi dari Social Support for Physical Activity (SSPA) yang sudah diadaptasi ke dalam bahasa Indonesia. ${ }^{(23)(24)}$ Terdiri dari 13 item pernyataan terkait dukungan yang diperoleh dari keluarga dan juga teman. Sedangkan untuk mengetahui promosi aktivitas fisik di tempat kerja, disusun beberapa ceklis pertanyaan terkait ketersediaan fasilitas dan kebijakan yang mendukung aktivitas fisik di tempat kerja. $^{(25)}$

Penelitian ini telah melalui proses kaji etik Komisi Etik Riset dan Pengabdian Kesehatan Masyarakat Fakultas Kesehatan Masyarkat Universitas Indonesia. Sebanyak 174 partisipan berpartisipasi dalam penelitian. Analisis statistik univariat dan bivariat dilakukan untuk mendapatkan gambaran responden yang berpartisipasi dan hubungan antara faktorfaktor dengan aktvitas fisik pekerja kantoran Jakarta. Analisis multivariat dilakukan untuk melihat faktor dominan yang berpengaruh terhadap aktivitas fisik responden.

\section{HASIL DAN PEMBAHASAN}

Tabel 1 menunjukkan gambaran karakteristik responden yaitu sebagian besar pekerja kantoran DKI Jakarta yang berpartisipasi dalam penelitian berada pada usia dewasa madya (74\%), berjenis kelamin wanita (64\%) dan menikah (67\%). Dilihat dari jenjang pendidikan, didominasi dengan pendidikan sarjana (64\%), kemudian diikuti dengan jenjang pascasarjana (27\%), diploma $(6 \%)$ dan SMA (2\%). Terkait instansi tempat kerja, $41 \%$ menyatakan bekerja pada intansi swasta dan $59 \%$ bekerja pada instansi pemerintah. Untuk lokasi kantor atau tempat kerja, $45 \%$ bekerja di wilayah Jakarta Selatan, 32\% di wilayah Jakarta 
Pusat, $15 \%$ di wilayah Jakarta Timur, 5\% di wilayah Jakarta Utara dan 3\% di wilayah Jakarta Barat. Gambaran pendapatan reponden pekerja kantoran di Jakarta dapat dilihat pada Tabel 2 dimana besar pendapatan rata-rata responden sebesar Rp 9.084.023,-.

Hasil pengukuran tingkat aktivitas fisik responden pekerja kantoran di Jakarta digambarkan pada Tabel 3. Terlihat bahwa responden pekerja kantoran yang bekerja di Jakarta lebih banyak masuk kategori kurang aktif yaitu sebesar 59\%. Ditemukan juga beberapa responden yang tidak melakukan aktivitas fisik sama sekali (skor METs =0) yaitu sebanyak 19\%. Terkait aktivitas sedentari, ditemukan rata-rata pekerja kantoran Jakarta melakukan aktivitas sedentari sebanyak 471 menit per hari atau hampir 8 jam per hari, yang kemungkinan merupakan aktivitas yang dilakukan selama waktu kerja.

Beberapa studi mengenai aktivitas fisik dari pekerja kantoran atau yang sering diistilahkan sebagai pekerja kerah putih (white-collar worker) menemukan hasil serupa. Hopkin dan Sarkar (2016) menyebutkan bahwa pekerja kantoran memiliki kecenderungan untuk kurang aktif fisik. Cukup banyaknya waktu yang dihabiskan di kantor (kurang lebih 8 jam per hari) dan aktivitas yang cenderung sedentari diduga menjadi penyebab kurang aktifnya para pekerja kantoran. Panjangnya durasi waktu kerja juga dinilai berhubungan terbalik dengan melakukan aktivitas fisik pada pekerja kantoran. ${ }^{(26)}$

Pekerjaan yang dilakukan pekerja kantoran cenderung tidak banyak memerlukan aktivitas fisik. Pemanfaatan teknologi membuat pekerja tidak lagi perlu bergerak aktif saat bekerja. ${ }^{(26)}$ Temuan penelitian ini menunjukkan hal yang sama, dilihat dari jenis aktivitas fisik yang dilakukan, seluruh responden tidak ada yang melakukan aktivitas fisik berat dalam bekerja. Hanya ada sedikit responden pekerja kantoran Jakarta yang menyatakan bahwa mereka melakukan aktivitas fisik sedang dalam bekerja.

Hasil analisis bivariat ditampilkan pada tabel 4. Uji chi-square menemukan hubungan bermakna antara aktivitas fisik dengan faktor jenis kelamin $p$ value = 0,002, perceived benefits dengan nilai $p$ value 0,013; perceived barriers dengan nilai $p$ value 0,002; dan dukungan teman dengan nilai $p$ value 0,013. Dengan demikian dapat diartikan bahwa jenis kelamin pria, perceived benefits yang kuat, perceived barriers yang lemah dan dukungan teman yang cukup merupakan faktor-faktor yang berhubungan dengan aktivitas fisik pekerja kantoran Jakarta.

Pekerja kantoran pria ditemukan lebih aktif fisik dibandingkan pekerja kantoran wanita. Hal ini sesuai dengan hasil penelitian di beberapa negara Asia, 
seperti Malaysia, Singapura dan Jepang, dimana pria hampir selalu ditemukan lebih aktif secara fisik dibandingkan dengan wanita. ${ }^{(9)(10)(12)(15)}$

Perceived barriers merupakan keyakinan akan adanya hambatanhambatan yang dirasa menghalangi untuk melakukan aktivitas fisik, seperti merasa tidak punya waktu, merasa lelah dan lemah, takut sakit atau cedera atau tidak adanya sarana dan fasilitas pendukung. Pekerja kantoran Jakarta dengan perceived barriers yang lemah, dua kali lebih besar kemungkinannya untuk melakukan aktivitas fisik yang cukup dibandingkan dengan pekerja kantoran yang memiliki perceived barriers yang kuat. Demikian halnya dengan variabel perceived benefits. Pekerja kantoran Jakarta dengan perceived benefits yang kuat dua kali lebih besar kemungkinannya untuk cukup aktif fisik dibandingkan dengan mereka yang perceived benefits-nya lemah. Memiliki keyakinan bahwa aktivitas fisik bermanfaat menjadi faktor yang berhubungan dengan aktivitas fisik. Hasil penelitian ini sesuai dengan penelitian yang dilakukan Trost dan kawan-kawan (2002) dimana perceived barriers menjadi faktor yang berhubungan dengan aktivitas fisik orang dewasa di negara Barat. Demikian halnya dengan penelitian di Jepang yang juga menemukan rendahnya persepsi negatif akan hambatan dan tingginya persepsi positif untuk melakukan aktivitas fisik ditemukan berhubungan dengan aktivitas fisik cukup pada orang dewasa, baik pria maupun wanita. ${ }^{(15)}$

Pekerja kantoran yang memperoleh dukungan teman atau mungkin juga rekan kerja mempunyai odds 2,28 lebih tinggi untuk dapat melakukan aktivitas fisik yang cukup sesuai rekomendasi yang bermanfaat untuk kesehatan daripada yang kurang dukungan teman. Bentuk dukungan yang diperoleh diantaranya berupa aktivitas olahraga bersama, mengingatkan untuk beraktivitas fisik, ataupun memberi semangat untuk aktif fisik.

Meski pada penelitian ini hanya dukungan teman yang ditemukan memiliki hubungan bermakna, namun tidak lantas dukungan keluarga menjadi faktor yang diabaikan. Hasil penelitian juga menunjukkan (Tabel 4), pada kelompok responden yang cukup aktif fisik, ditemukan lebih banyak yang merasa memperoleh dukungan keluarga yang cukup daripada yang merasa kurang memperoleh dukungan keluarga. Selain itu, $65,4 \%$ responden pekerja kantoran Jakarta dengan dukungan keluarga kurang ditemukan kurang aktif fisik.

Berbagai penelitian di berbagai negara banyak yang menemukan hasil yang sama dimana dukungan sosial, baik dari teman maupun keluarga, berperan terhadap aktivitas fisik orang 
dewasa. ${ }^{(1)(15)(16)}$ Demikian halnya juga penelitian di Indonesia yang dilakukan Pawitaningtyas (2017) pada wanita pasca menopause dengan obesitas sentral di salah satu kelurahan Kota Depok, mereka yang mendapat dukungan sosial berpeluang 3,5 kali lebih tinggi untuk dapat melakukan aktivitas fisik cukup dibandingkan dengan yang tidak memperoleh dukungan sosial. Hasil penelitian ini menunjukkan pentingnya upaya promosi aktivitas fisik yang tidak hanya mensasar individu tetapi juga mensasar kelompok, komunitas, baik kelompok masyarakat terkecil yaitu keluarga atau dalam konteks pekerja dapat juga mensasar instansi tempat bekerja.

Analisis multivariat regresi logistik model determinan kemudian dilakukan untuk mengetahui faktor yang paling dominan berhubungan dengan aktivitas fisik pekerja kantoran di Jakarta. Keempat variabel yang ditemukan memiliki hubungan bermakna pada analisis bivariat kemudian dimasukkan ke dalam analisis multivariat.

Berdasarkan analisis multivariat (Tabel 5), variabel yang berpengaruh signifikan dengan aktivitas fisik adalah jenis kelamin, dukungan teman dan perceived barriers. Variabel perceived benefits merupakan variabel pengontrol. Variabel yang paling dominan berhubungan dengan aktivitas fisik adalah jenis kelamin $(\mathrm{OR}=2,916)$ dimana laki-laki mempunyai odds ratio 2 kali lebih tinggi untuk lebih aktif fisik dibandingkan perempuan setelah dikontrol dukungan teman, perceived barriers dan perceived benefits.

Tabel 1. Distribusi responden menurut usia, jenis kelamin, status nikah, dan pendidikan di Jakarta tahun 2018

\begin{tabular}{lcc}
\hline \multicolumn{1}{c}{ Variabel } & $\mathrm{n}=174$ & Persentase (100\%) \\
\hline Usia & 45 & 26 \\
Dewasa muda (21-29 tahun) & 129 & 74 \\
Dewasa Madya (30-58 tahun) & 62 & 36 \\
\hline Jenis Kelamin & 112 & 64 \\
$\quad$ Pria & & \\
Wanita & 58 & 33 \\
\hline Status Nikah & 116 & 67 \\
Lajang & & \\
Menikah & 3 & 6 \\
Pendidikan & 11 & 64 \\
SMA & 112 & 27 \\
Diploma & 47 & \\
Sarjana & & \\
Pascasarjana & & \\
\hline
\end{tabular}




\begin{tabular}{lcc}
\hline Jenis Instansi Tempat Kerja & \\
Swasta & 72 & 41 \\
Pemerintah & 102 & 59 \\
\hline Lokasi Tempat Kerja & & \\
Jakarta Pusat & 55 & 32 \\
Jakarta Selatan & 79 & 45 \\
Jakarta Barat & 5 & 3 \\
Jakarta Utara & 8 & 5 \\
Jakarta Timur & 27 & 15 \\
\hline
\end{tabular}

Tabel 2. Distribusi responden menurut pendapatan di Jakarta tahun 2018

\begin{tabular}{|c|c|c|c|c|c|}
\hline Variabel & $\begin{array}{c}\mathrm{n} \\
(174)\end{array}$ & $\begin{array}{c}\text { Persentase } \\
(100 \%)\end{array}$ & Rata-rata & $\begin{array}{l}\text { Standar } \\
\text { Deviasi }\end{array}$ & $\begin{array}{l}\text { Minimun - } \\
\text { Maksimum }\end{array}$ \\
\hline Pendapatan & & & Rp 9.084.023 & $\operatorname{Rp} 6.846 .839$ & $\operatorname{Rp} 2.000 .000$ \\
\hline $\begin{array}{l}\text { Rendah } \\
(<\operatorname{Rp} 5.250 .000,-)\end{array}$ & 42 & 24 & & & $\begin{array}{l}- \\
\operatorname{Rp} 55.000 .000\end{array}$ \\
\hline $\begin{array}{l}\text { Menengah } \\
\text { (Rp 5.250.000 - Rp } \\
10.000 .000,-)\end{array}$ & 101 & 58 & & & \\
\hline $\begin{array}{l}\text { Tinggi } \\
\text { (> Rp 10.000.000,) }\end{array}$ & 31 & 18 & & & \\
\hline
\end{tabular}

Tabel 3. Distribusi responden berdasarkan tingkat aktivitas fisik di Jakarta tahun 2018

\begin{tabular}{cccccc}
\hline Variabel & $\begin{array}{c}\mathrm{n} \\
(174)\end{array}$ & $\begin{array}{c}\text { Persentase } \\
(100 \%)\end{array}$ & $\begin{array}{c}\text { Rata-Rata } \\
\text { Aktivitas fisik total (METs) }\end{array}$ & $\begin{array}{c}\text { Standar } \\
\text { Deviasi }\end{array}$ & $\begin{array}{c}\text { Minimum- } \\
\text { Maksimum }\end{array}$ \\
Cukup (METs $\geq 600)$ & 71 & 41 & 1047 & 1663,7 & $0-9360$ \\
Kurang (METs $<600)$ & 103 & 59 & & & \\
\hline
\end{tabular}

Tabel 4. Distribusi responden berdasarkan karakteristik individu dan aktivitas fisik

\begin{tabular}{|c|c|c|c|c|c|}
\hline \multirow[t]{2}{*}{ Karakteristik Individu } & \multicolumn{2}{|c|}{ Aktivitas Fisik } & \multirow{2}{*}{$\begin{array}{l}\text { Total } \\
\mathrm{n}(\%)\end{array}$} & \multirow{2}{*}{$\begin{array}{l}\text { Nilai } \\
\text { p }\end{array}$} & \multirow{2}{*}{$\begin{array}{c}\text { OR } \\
(95 \% \mathrm{Cl})\end{array}$} \\
\hline & $\begin{array}{l}\text { Cukup } \\
\mathrm{n}(\%)\end{array}$ & $\begin{array}{c}\text { Kurang } \\
\mathrm{n}(\%)\end{array}$ & & & \\
\hline Usia & & & & 1 & 1,048 \\
\hline $\begin{array}{l}\text { Dewasa muda (21-29 } \\
\text { thn) }\end{array}$ & $19(42,2)$ & $26(57,8)$ & $45(100)$ & & $(0,53-2,08)$ \\
\hline $\begin{array}{l}\text { Dewasa Madya (30-58 } \\
\text { thn) }\end{array}$ & $53(41,1)$ & $76(58,9)$ & $129(100)$ & & \\
\hline Jenis Kelamin & & & & 0,002 & 2,923 \\
\hline Pria & $36(58,1)$ & $26(41,9)$ & $62(100)$ & & $(1,54-5,55)$ \\
\hline Wanita & $36(32,1)$ & $76(67,9)$ & $112(100)$ & & \\
\hline Status Nikah & & & & 1 & 1 \\
\hline Lajang & $24(41,1)$ & $34(58,6)$ & $58(100)$ & & $(0,53-1,70)$ \\
\hline Menikah & $48(41,1)$ & $68(58,6)$ & $116(100)$ & & \\
\hline Pendidikan & & & & 0,324 & 0,669 \\
\hline SMA & $2(66,7)$ & $1(33,3)$ & $3(100)$ & & $(0,34-1,31)$ \\
\hline Diploma \& Sarjana & $47(38,2)$ & $76(61,8)$ & $123(100)$ & & \\
\hline
\end{tabular}




\begin{tabular}{|c|c|c|c|c|c|}
\hline Pascasarjana & $23(47,9)$ & $25(52,1)$ & $48(100)$ & & \\
\hline $\begin{array}{l}\text { Pendapatan } \\
\text { Rendah } \\
\text { Menengah } \\
\text { Tinggi }\end{array}$ & $\begin{array}{l}18(42,9) \\
38(37,6) \\
16(51,6)\end{array}$ & $\begin{array}{l}24(57,1) \\
63(62,4) \\
15(48,4)\end{array}$ & $\begin{array}{l}42(100) \\
101(100) \\
31(100)\end{array}$ & 0,375 & $\begin{array}{c}0,979 \\
(0,49-1,94)\end{array}$ \\
\hline $\begin{array}{l}\text { Indeks Massa Tubuh } \\
\text { Tidak Obesitas } \\
\text { Obesitas }\end{array}$ & $\begin{array}{l}54(43,2) \\
18(36,7)\end{array}$ & $\begin{array}{l}71(56,8) \\
31(63,3) \\
\end{array}$ & $\begin{array}{c}125(100) \\
49(100)\end{array}$ & 0,543 & $\begin{array}{c}0,763 \\
(0,39-1,51)\end{array}$ \\
\hline $\begin{array}{l}\text { Riwayat Penyakit } \\
\text { Tidak Ada } \\
\text { Ada } \\
\end{array}$ & $\begin{array}{c}59(41,5) \\
8(53,3) \\
\end{array}$ & $\begin{array}{c}83(58,5) \\
7(46,7) \\
\end{array}$ & $\begin{array}{c}142(100) \\
15(100)\end{array}$ & 0,546 & $\begin{array}{c}0,963 \\
(0,44-2,10)\end{array}$ \\
\hline $\begin{array}{l}\text { Perceived Benefits } \\
\text { Kuat }(\geq \text { rata-rata) } \\
\text { Lemah (< rata-rata) } \\
\end{array}$ & $\begin{array}{l}47(50,5) \\
25(30,9) \\
\end{array}$ & $\begin{array}{l}46(49,5) \\
56(69,1) \\
\end{array}$ & $\begin{array}{l}93(100) \\
81(100)\end{array}$ & 0,013 & $\begin{array}{c}2,289 \\
(1,23-4,27)\end{array}$ \\
\hline $\begin{array}{l}\text { Perceived Barriers } \\
\text { Lemah }(\geq \text { rata-rata) } \\
\text { Kuat }(<\text { rata-rata) }\end{array}$ & $\begin{array}{c}51(52) \\
21(27,6)\end{array}$ & $\begin{array}{c}47(48) \\
55(72,4)\end{array}$ & $\begin{array}{l}98(100) \\
76(100)\end{array}$ & 0,002 & $\begin{array}{c}2,842 \\
(1,49-5,39)\end{array}$ \\
\hline $\begin{array}{l}\text { Dukungan Keluarga } \\
\text { Cukup }(\geq \text { median }) \\
\text { Kurang }(<\text { median })\end{array}$ & $\begin{array}{l}45(46,9) \\
27(34,6)\end{array}$ & $\begin{array}{l}51(53,1) \\
51(65,4)\end{array}$ & $\begin{array}{l}96(100) \\
78(100)\end{array}$ & 0,139 & $\begin{array}{c}1,667 \\
(0,91-3,80)\end{array}$ \\
\hline $\begin{array}{l}\text { Dukungan Teman } \\
\text { Cukup }(\geq \text { median }) \\
\text { Kurang }(<\text { median })\end{array}$ & $\begin{array}{l}45(51,1) \\
27(31,4)\end{array}$ & $\begin{array}{l}43(48,9) \\
59(68,6)\end{array}$ & $\begin{array}{l}88(100) \\
86(100)\end{array}$ & 0,013 & $\begin{array}{c}2,287 \\
(1,23-4,24)\end{array}$ \\
\hline $\begin{array}{l}\text { Promosi Aktivitas Fisik di } \\
\text { Tempat Kerja } \\
\text { Cukup }(\geq \text { median }) \\
\text { Kurang }(<\text { median })\end{array}$ & $\begin{array}{l}51(42,9) \\
21(38,2)\end{array}$ & $\begin{array}{l}68(57,1) \\
34(61,8)\end{array}$ & $\begin{array}{l}119(100) \\
55(100)\end{array}$ & 0,677 & $\begin{array}{c}1,214 \\
(0,63-2,34)\end{array}$ \\
\hline $\begin{array}{l}\text { Transportasi aktif } \\
\text { Melakukan } \\
\text { Tidak melakukan }\end{array}$ & $\begin{array}{l}33(45,8) \\
39(38,2)\end{array}$ & $\begin{array}{l}39(54,2) \\
63(61,8)\end{array}$ & $\begin{array}{c}72(100) \\
102(100)\end{array}$ & 0,398 & $\begin{array}{c}1,367 \\
(0,74-2,52)\end{array}$ \\
\hline
\end{tabular}

Tabel 5. Hasil pemodelan multivariat aktivitas fisik pada pekerja kantoran yang bekerja di Jakarta tahun 2018

\begin{tabular}{llcccc}
\hline & Variabel & $\mathrm{B}$ & p-value & OR & $95 \%$ CI \\
\hline 1. Jenis Kelamin & 1,070 & 0,002 & 2,916 & $1,479-5,751$ \\
2. Dukungan Teman & 0,840 & 0,021 & 2,316 & $1,133-4,732$ \\
3. Perceived Barriers & 0,783 & 0,028 & 2,187 & $1,088-4,397$ \\
4. & Perceived Benefits & 0,362 & 0,326 & 1,436 & $0,698-2,954$ \\
\hline
\end{tabular}

Variabel dukungan teman memperoleh OR sebesar 2,316 atau dapat dikatakan bahwa pekerja kantoran di Jakarta yang mempunyai dukungan teman mempunyai odds 2 kali lebih tinggi untuk lebih aktif fisik dibandingkan dengan yang kurang dukungan dari teman. Demikian juga dengan variabel perceived barriers yang memperoleh OR sebesar 2,187 dapat dikatakan pekerja kantoran di Jakarta yang mempunyai perceived barriers yang lemah 2 kali lebih tinggi untuk lebih aktif fisik dibandingkan yang perceived barriers-nya kuat. 


\section{SIMPULAN}

Hasil penelitian menemukan faktorfaktor yang berhubungan dengan aktivitas fisik pekerja kantoran di Jakarta adalah jenis kelamin pria, dukungan teman dan perceived barriers yang lemah. Aktivitas fisik merupakan salah satu perilaku yang saat ini dikampanyekan dalam program pemerintah di bidang kesehatan. ${ }^{(27)}$ Pekerja kantoran merupakan bagian dari populasi orang dewasa yang berisiko kurang aktivitas fisik dikarenakan banyaknya waktu yang dihabiskan untuk bekerja dan pekerjaanya yang cenderung sedentari.

Temuan dari penelitian ini diharapkan dapat menjadi pesan yang disampaikan dalam upaya peningkatan aktivitas fisik masyarakat usia dewasa, khususnya pekerja kantoran. Upaya dilakukan dapat berbentuk intervensi atau program peningkatan aktivitas fisik yang dilakukan oleh perusahaan ataupun instansi tempat kerja yang bertujuan mengurangi persepsi negatif akan hambatan-hambatan yang dirasa terkait aktivitas fisik sekaligus meningkatkan persepsi positif akan keuntungan yang diperoleh dengan melakukan aktivitas fisik tersebut. Memberikan berbagai informasi mengenai manfaat dari aktivitas fisik yang cukup, minimal untuk meningkatkan kesehatan, dengan mensiasati waktu semaksimal mungkin untuk dapat beraktifitas fisik di tengah kesibukan kerja dan kesibukan lainnya maupun berbagai macam kegiatan yang dapat menjadi muatan program. Melakukan kampanye bersama tokoh masyarakat yang dapat menjadi duta aktivitas fisik pekerja kantoran juga dapat dilakukan.

Temuan penelitian terkait dukungan teman juga diharapkan dapat menjadi masukan dalam penyusunan intervensi promosi kesehatan untuk meningkatkan aktivitas fisik pekerja kantoran. Mendorong pekerja kantoran untuk beraktivitas fisik bersama-sama dengan rekan maupun keluarga dapat menjadi upaya yang perlu dilakukan. Jika di kantor, perusahaan atau instansi tempat kerja diketahui terdapat pegawai-pegawai yang giat melakukan aktivitas fisik, maka mereka dapat dijadikan sebagai agen kampanye. Hal ini tentunya perlu disertai dengan rencana program promosi kesehatan yang berkesinambungan, serta adanya dukungan dan komitmen dari organisasi kantor, perusahaan atau instansi tempat kerja. Penyusunan intervensi atau program promosi aktivitas fisik yang lebih spesifik mensasar kelompok pekerja kantoran wanita dirasa perlu dilakukan mengingat cukup besarnya ditemukan pekerja wanita yang kurang aktif fisik. Pengukuran tingkat aktivitas fisik dalam penelitian ini hanya dilakukan menggunakan kuesioner. Penggunaan metode pengukuran aktivitas fisik yang 
lebih objektif seperti sensor gerak ataupun pedometer dapat dilakukan ke depan untuk dapat memberikan gambaran aktivitas fisik yang lebih objektif dilakukan oleh responden penelitian.

\section{KEPUSTAKAAN}

1. Bauman AE, Reis RS, Sallis JF, Wells JC, Loos RJ, Martin BW. Correlates of physical activity: why are some people physically active and others not? Lancet [Internet]. 2012 [cited 2017 Mar 22];380. Available from: http://ac.elscdn.com/S0140673612607351/1s2.0-S0140673612607351main.pdf?_tid=d99b7e3c-0ed311e7-b58e-

00000aab0f02\&acdnat $=1490169051$ _ 163f8e45f3d56b4b8dae28e00497d $20 \mathrm{e}$

2. Hallal PC, Andersen LB, Bull FC, Guthold R, Haskell W, Ekelund U. Global physical activity levels: surveillance progress, pitfalls, and prospects. Lancet [Internet]. 2012 Jul [cited 2017 Mar 22];380(9838):247-57. Available from:

http://linkinghub.elsevier.com/retrie ve/pii/S0140673612606461

3. Macera CA, Hootman JM, Sniezek JE. Major public health benefits of physical activity. Arthritis Rheum
[Internet]. 2003;49(1):122-8.

Available from: http://doi.wiley.com/10.1002/art.109 07

4. Lee I-M, Shiroma EJ, Lobelo F, Puska P, Blair SN, Katzmarzyk PT. Effect of physical inactivity on major non-communicable diseases worldwide: an analysis of burden of disease and life expectancy. Lancet [Internet]. 2012 Jul [cited 2017 Mar 22];380(9838):219-29. Available from:

http://linkinghub.elsevier.com/retrie ve/pii/S0140673612610319

5. Biddle BS, Mutrie N. Psychology of Physical Activity: Determinants, well-being and interventions 2nd edition [Internet]. 2nd ed. Routledge. London: Routledge; 2008. Available from: http://www.routledge.com/books/det ails/9780415518185/

6. WHO | Prevalence of insufficient physical activity. WHO [Internet]. 2015 [cited 2017 May 29]; Available from: http://www.who.int/gho/ncd/risk_fa ctors/physical_activity_text/en/

7. Riset Kesehatan Dasar 2013. 2013.

8. Pradesha NT. Hasil Survei: Warga Jakarta Kebanyakan Kerja, Kurang Olahraga [Internet]. CNN Indonesia. 2015 [cited 2017 Nov 29]. Available 
from:

https://www.cnnindonesia.com/gaya

-hidup/20150519174526-255-

54296/hasil-survei-warga-jakarta-

kebanyakan-kerja-kurang-olahraga/

9. Cheah YK, Poh BK. The

Determinants of Participation in

Physical Activity in Malaysia.

Osong Public Heal Res Perspect

[Internet]. 2014 [cited 2017 Apr

14];5:20-7. Available from:

https://www.ncbi.nlm.nih.gov/pmc/a

rticles/PMC4064643/pdf/main.pdf

10. Teh CH, Lim KK, Chan YY, Lim KH, Azahadi O, Akmar AHH, et al. The prevalence of physical activity and its associated factors among Malaysian adults : findings from the National Health and Morbidity Survey 2011. Public Health [Internet]. 2014;128(5):416-23. Available from: http://dx.doi.org/10.1016/j.puhe.201 3.10 .008

11. Bui T Van, Blizzard CL, Luong KN, Truong NL Van. Physical Activity in Vietnam: Estimates and Measurement Issues. J Plos One [Internet]. 2015; Available from: http://dx.doi.org/10.1371/journal.po ne.0140941

12. Win $\mathrm{AM}, \operatorname{Lim} \mathrm{W}$, Yen $\mathrm{K}, \mathrm{Hx} \mathrm{T}$, Boon R, Lim T, et al. Patterns of physical activity and sedentary behavior in a representative sample of a multi-ethnic South-East Asian population: a cross-sectional study. BMC Public Health [Internet]. 2015 [cited 2017 Aug 4];15. Available from:

https://bmcpublichealth.biomedcentr al.com/track/pdf/10.1186/s12889-

015-1668-

7? site $=$ bmcpublichealth. biomedcent ral.com

13. Jurj AL, Wen W, Gao Y-T, Matthews CE, Yang G, Li H-L, et al. Patterns and correlates of physical activity: a cross-sectional study in urban Chinese women. BMC Public Health. 2007;7:213.

14. Ibrahim S, Karim NA, Oon NL, Zurinah W, Ngah W. Perceived physical activity barriers related to body weight status and sociodemographic factors among Malaysian men in Klang Valley. 2013 [cited 2017 Nov 30]; Available from:

https://www.ncbi.nlm.nih.gov/pmc/a rticles/PMC3617120/pdf/14712458-13-275.pdf

15. Shibata A, Oka K, Harada K, Nakamura Y, Muraoka I. Psychological, social, and environmental factors to meeting physical activity recommendations among Japanese adults. Int J Behav 
Nutr Phys Act [Internet]. 2009 [cited 2017 Nov 30];6(6). Available from:

http://www.ijbnpa.org/content/6/1/6 0

16. Trost SG, Owen N, Bauman AE, Sallis JF, Brown W. Correlates of adults participation in physical activity: review and update. Med Sci Sport Exerc [Internet]. 2002 [cited 2017 Apr 25];34(12). Available from: https://www.researchgate.net/profile /Stewart_Trost/publication/1100108 8_Correlates_of_adults\%27_particip ation_in_physical_activity_Review_ and_update/links/57031b3808aea09 bb1a3089f/Correlates-of-adultsparticipation-in-physical-activityReview-and-update.p

17. Blackwell DL, Clarke TC. Occupational Differences Among Employed Adults Who Met 2008 Federal Guidelines for Both Aerobic and Muscle-strengthening Activities: United States, 20082014. Natl Heal Stat Rep [Internet]. 2016 [cited 2017 Dec 27];94. Available from: https://www.cdc.gov/nchs/data/nhsr/ nhsr094.pdf

18. Wanner M, Götschi T, MartinDiener E, Kahlmeier S, Martin BW. Active Transport, Physical Activity, and Body Weight in Adults: A Systematic Review. Am J Prev Med [Internet]. 2012 May 1 [cited 2018 Jan 25];42(5):493-502. Available from:

https://www.sciencedirect.com/scien ce/article/pii/S0749379712000918? via\%3Dihub

19. Warga Kurang Aktivitas Fisik. Harian Kompas. 2017 Sep 8;10.

20. World Health Organization. Global Physical Activity Questionnaire. 2010;380(9838):282-93. Available from:

http://www.who.int/chp/steps/resour ces/GPAQ_Analysis_Guide.pdf

21. Pramesti RAAY. Hubungan faktor pengetahuan, riwayat diabetes mellitus keluarga dan faktor yang dapat dimodifikasi dengan kejadian diabetes mellitus tipe 2 di kecamatan kepulauan seribu utara kabupaten administrasi kepulauan seribu tahun 2016. Universitas Indonesia; 2016.

22. Sechrist KR, Walker S., Pender NJ. Health Promotion Model Instruments to Measure HPM Behavioral Determinants: Exercise Social Support Scale. 1995; Available from: http://deepblue.lib.umich.edu/handle /2027.42/85345

23. Sallis JF, Grossman RM, Pinski RB, 
Patterson TL, Nader PR. The development of scales to measure social support for diet and exercise behaviors. Prev Med (Baltim) [Internet]. 1987 Nov [cited 2017 Dec 19];16(6):825-36. Available from:

http://linkinghub.elsevier.com/retrie ve/pii/0091743587900223

24. Juwono ID. Social Support for Diet and Exercise: Survey (Bahasa Indonesian) [Internet]. [cited 2018 Apr 23]. Available from: http://sallis.ucsd.edu/measure_social support.html

25. Crespo NC, Sallis JF, Conway TL, Saelens BE, Frank LD. Worksite Physical Activity Policies and Environments in Relation to Employee Physical Activity. Am J
Heal Promot [Internet]. 2011 [cited 2018 Jan 10];25(4). Available from: http://remote-

lib.ui.ac.id:5914/doi/pdf/10.4278/ajh p.081112-QUAN-280

26. Kirk MA, Rhodes RE. Occupation correlates of adults' participation in leisure-time physical activity: A systematic review. Am J Prev Med. 2011;40(4):476-85.

27. Kementerian Kesehatan RI. Buku Panduan GERMAS (Gerakan Masyarakat Hidup Sehat) [Internet]. Jakarta; 2017 [cited 2017 Dec 15]. Available from: http://dinkes.acehprov.go.id/uploads /buku-panduan-germas-final.pdf 